\title{
Portfolio flows and the US dollar-yen exchange rate
}

\author{
Faek Menla Ali ${ }^{1}$. Fabio Spagnolo ${ }^{1}$. \\ Nicola Spagnolo ${ }^{1,2}$
}

Received: 20 October 2014 / Accepted: 25 January 2016 / Published online: 9 April 2016

(C) The Author(s) 2016. This article is published with open access at Springerlink.com

\begin{abstract}
This paper investigates the effects of portfolio flows on the US dollarJapanese yen exchange rate changes over the period 1988:01-2011:04. Using a time-varying transition probability Markov-switching framework, the results suggest that the impact of portfolio flows on the dollar-yen exchange rate changes is statedependent. In particular, the results show that portfolio inflows from Japan toward the US, more than monetary variables, strengthen the probability of remaining in the dollar-yen appreciation (low volatility) state. Therefore, credit controls on the flows can be used as a policy tool to pursue economic and financial stability.
\end{abstract}

Keywords Exchange rates $\cdot$ Portfolio flows $\cdot$ Regime-switching

JEL Classification F31 $\cdot$ F32 - G15

\section{Introduction}

Over the recent years, there has been a significant attention on the cross-border portfolio flows effects on exchange rate changes and its volatility. The general view is that large inflows result in an exchange rate appreciation. Nonetheless, volatile crossborder flows may lead to an increase in the volatility of the exchange rates. In this

We would like to thank O. Cassero, the editor (Robert M. Kunst), and two anonymous referees for useful comments and suggestions.

$凶 \quad$ Faek Menla Ali

faek.menlaali@brunel.ac.uk

1 Department of Economics and Finance, Brunel University London,

Uxbridge, Middlesex UB8 3PH, UK

2 Centre for Applied Macroeconomic Analysis (CAMA), Canberra, Australia 


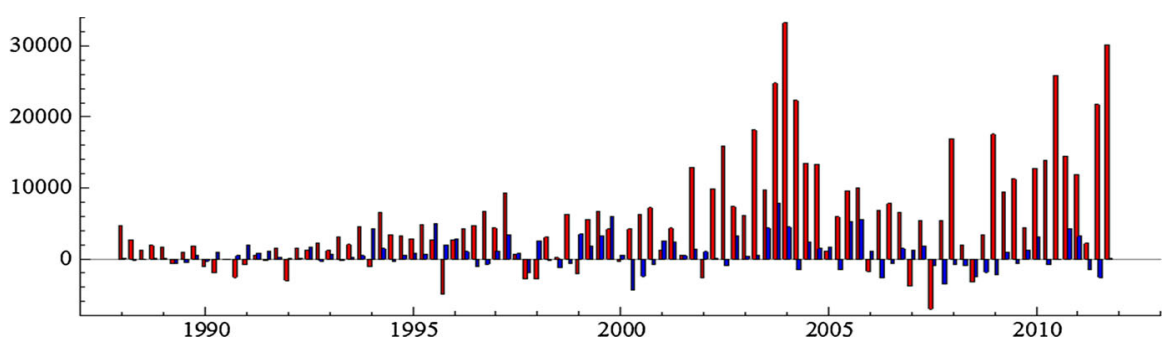

Fig. 1 Evolution of gross portfolio inflows from Japan toward the US (in red) and from the US toward Japan (in blue) (in millions of US dollars). Source: US TIC. (Color figure online)

paper, we examine to what extent equity and bond portfolio flows between the US and Japan affect the corresponding US dollar-yen exchange rate changes, given that the cross-border acquisition of long-term securities between these countries has grown over the recent years (see Fig. 1). The US listed stocks of Japanese companies have been substantially larger compared to the other developed countries. Also, the Bank of Japan has frequently exercised what is known as the sterilized intervention in the foreign exchange market using long-term, primarily US, bond instruments to tackle the stagnation of the Japanese economy. ${ }^{1}$ As Sarno et al. (2016) documented, bond flows between the US and Japan have also been driven by the so-called yen carry trade, where investors borrowed in yen at the very low rates to invest in high interest currencies, mainly the US dollar. ${ }^{2}$

The lack of academic consensus on what factors explain the dollar-yen exchange rate changes further motivates this study. Obstfeld (2009) comments that "the determinants of the yen's short- and even longer-term movements remain mysterious in light of the development of Japan's macro economy". Ruelke et al. (2010), by using the Wall Street Journal poll, further discuss on the findings that forecasters can be regarded as heterogeneous in the expectation formation process for the yen against the US dollar over the period 1989-2007. Recent studies on the determinants of the US dollar-yen exchange rate also include Chinn and Moore (2011) and Hunter and Menla Ali (2014), among others.

More specifically, this paper contributes to the existing literature by examining the nonlinear impact of cross-border portfolio flows on dollar-yen exchange rate changes. Most of the existing empirical studies have assumed a linear framework (see, e.g., Brooks et al. 2004; Hau and Rey 2006). However, the nonlinear effects of flows on exchange rates have drawn less attention, even though the existence of multiple equilibria in the behavior of the exchange rate and its volatility has been well documented (e.g., Jeanne and Rose 2002; Lovcha and Perez-Laborda 2013, among others). The only exception is the study by Menla Ali et al. (2014), who used a fixed transition probability Markov-switching specification and found that net bond flows have a significant impact on dollar-yen exchange rate changes only in periods of low volatility.

\footnotetext{
1 Sarno and Taylor (2001) argued that the sterilized intervention affects the exchange rate through what is known as "portfolio balance effect" and "signaling effect".

2 It was estimated that about one trillion US dollars was at stake in the yen carry trade by early 2007 (The Economist 2007).
} 

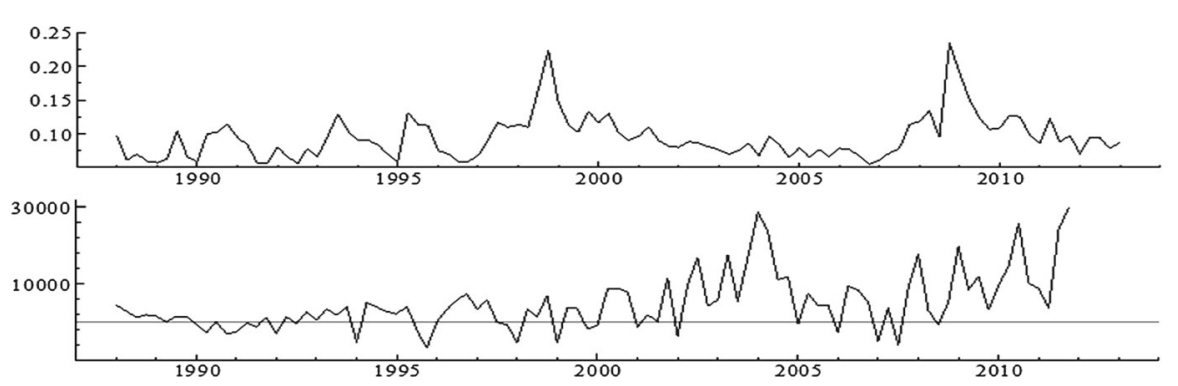

Fig. 2 Net portfolio inflows (in millions of US dollars) from Japan toward the US (lower panel) and the annualized historical volatility of the dollar-yen exchange rate changes (upper panel)

Considering the recent evidence of Menla Ali et al. (2014) on nonlinear dependence, this paper uses the time-varying transition probability Markov-switching framework as an alternative way to examine the nonlinear impact of the flows on the dollar-yen exchange rate changes. The adopted framework is flexible enough to capture the nonlinearity in the relationship between exchange rate changes and portfolio flows as it separates periods of appreciation from periods of depreciation and of high volatility from those of low volatility allowing the probabilistic structure of the transition from one regime to the next be a function of the flows. The causal effect is not constrained to be symmetric in the parameterization (portfolio flows affect the exchange rate differently in periods of appreciation and depreciation, as well as high and low volatility) and in the temporal causality (portfolio flows have a different impact on the future exchange rate in periods of appreciation and depreciation, as well as high and low volatility). The model, therefore, measures the impact of portfolio flows for different states of the currency. ${ }^{3}$

Intuitively, portfolio flows may not be the same during periods of appreciation and depreciation and also when the currency is highly volatile and less volatile. In fact, there is now evidence that international flows change with the level of uncertainty in the foreign exchange markets. Caporale et al. (2015) found specifically that international inflows toward the US were dampened during high uncertainty of exchange rate changes using data from major developed countries. Figure 2 displays the evolution of the net portfolio inflows from Japan toward the US and the annualized historical volatility of the dollar-yen exchange rate changes. A graphical inspection suggests that periods associated with large increases (declines) in the inflows correspond to those of relatively low (high) volatility of exchange rate changes.

The adopted nonlinear analysis is further of paramount interest, given that the safe haven feature of the yen during certain periods, such as the period of the global financial crisis, has been documented by several studies. Habib and Stracca (2012) reported that safe haven currencies, per se, tend to have a stronger net foreign asset position. It follows that portfolio flows' behavior is likely to be different during periods when the currency acts as a safe haven. ${ }^{4}$

\footnotetext{
3 For more details, see Filardo (1994).

${ }^{4}$ However, Botman et al. (2013) recently concluded that neither capital inflows nor expectations of the future monetary policy stance can give an explanation to the yen's safe haven behavior.
} 
The nonlinear mechanism adopted in this paper offers important policy implications. Policy makers and regulators can set appropriate policies with regard to economic and financial stability. For example, policies aimed to ease the impact of currency appreciation, and the associated negative effects on the economy could be unsuccessful if higher inflows move the exchange rate to the appreciation regime. Credit controls on the flows may be deemed in this regard, since such a policy is likely to mute the inflows, and hence stabilize the economy.

The remainder of this paper is organized as follows. Section 2 outlines the econometric model and the hypotheses tested in this study. Section 3 describes the data and discusses the empirical results, and Sect. 4 concludes.

\section{The model}

The time-varying regime-switching model considered in this paper allows for shifts in mean-variance, that is, for periods of appreciation and depreciation and low and high volatility, and is given by:

$$
\begin{gathered}
r_{t}=\mu\left(s_{t}\right)+\sum_{i=1}^{4} \phi_{i} r_{t-i}+\sigma\left(s_{t}\right) \varepsilon_{t}, \quad(t \in \mathbb{T}), \\
\mu\left(s_{t}\right)=\sum_{i=1}^{2} \mu_{(i)} \mathbf{1}\left\{s_{t}=i\right\}, \quad \sigma\left(s_{t}\right)=\sum_{i=1}^{2} \sigma_{(i)} \mathbf{1}\left\{s_{t}=i\right\},
\end{gathered}
$$

where $r_{t}$ denotes the log changes in the US dollar-Japanese yen exchange rate. Autoregressive terms (up to four lags) are also considered. Therefore, the parameter vector of the mean equation, (Eq. 1), is defined by $\mu_{(i)}(i=1,2)$ and $\sigma_{(i)}(i=1,2)$ which are real constants, the autoregressive terms $\sum_{i=1}^{4} \phi_{i},\left\{\varepsilon_{t}\right\}$ which are i.i.d. errors with $\mathrm{E}\left(\varepsilon_{t}\right)=0$ and $\mathrm{E}\left(\varepsilon_{t}^{2}\right)=1$, and the random variables $\left\{s_{t}\right\}$ in $\mathbb{S}=\{1,2\}$ which indicate the unobserved state of the process at time $t$. Throughout, the regime indicators $\left\{s_{t}\right\}$ are assumed to form a Markov chain on $\mathbb{S}$ with transition probability matrix $\mathbf{P}^{\prime}=\left[p_{i j}\right]_{2 \times 2}$, where $p_{i j}=\operatorname{Pr}\left(s_{t}=j \mid s_{t-1}=i\right)$ with $i, j \in \mathbb{S} . p_{i 1}=1-p_{i 2}(i \in \mathbb{S})$, where each column sums to unity, and all elements are nonnegative. It is also assumed that $\left\{\varepsilon_{t}\right\}$ and $\left\{s_{t}\right\}$ are independent.

To assess the links between net portfolio flows and the dollar-yen exchange rate changes, we generalize the model in Eq. (1) by allowing the transition probabilities to vary over time. In particular, we assume that each conditional mean follows an independent regime-shifting process and, following Filardo (1994), the transition mechanism governing $\left\{s_{t}\right\}$ is given by (Model 1):

$$
\begin{aligned}
& p_{t}^{1}=\frac{\exp \left(\gamma_{0}+\gamma_{1} n p f_{t-1}\right)}{\left[1+\exp \left(\gamma_{0}+\gamma_{1} n p f_{t-1}\right)\right]}, \\
& p_{t}^{2}=\frac{\exp \left(\eta_{0}+\eta_{1} n p f_{t-1}\right)}{\left[1+\exp \left(\eta_{0}+\eta_{1} n p f_{t-1}\right)\right]} .
\end{aligned}
$$


Note that since $p_{t}^{1} / n p f_{t-1}$ has the same sign as $\gamma_{1}, \gamma_{1}>0$ implies that an increase in net portfolio inflows, $n p f_{t-1}$, increases the probability of remaining in state 1 . Similarly, $\eta_{1}>0$ implies that an increase in $n p f_{t-1}$ will increase the probability of remaining in the second regime. ${ }^{5}$

For robustness purposes, the following control variables are considered: stock market return differential $\left(s-s^{*}\right)_{t-1}$, short-term interest rate differential $\left(i-i^{*}\right)_{t-1}$ and real oil price changes oil $t_{-1} \cdot{ }^{6}\left(s-s^{*}\right)_{t-1}$ captures stock market shocks across the US and Japan. $\left(i-i^{*}\right)_{t-1}$ controls for the different monetary policies between the US and Japan as a result of the different inflationary environments over the period under investigation (see Bernanke 2000). oil $t_{-1}$ is aimed to capture the terms of trade shocks (Amano and Norden 1998) as both the US and Japan are net importer countries and the input costs in the two countries are highly sensitive to oil price changes. Therefore, the extended model (Model 2) has the following form:

$$
\begin{aligned}
p_{t}^{1} & =\frac{\exp \left(\gamma_{0}+\gamma_{1} n p f_{t-1}+\gamma_{2}\left(s-s^{*}\right)_{t-1}+\gamma_{3}\left(i-i^{*}\right)_{t-1}+\gamma_{4} \mathrm{oil}_{t-1}\right)}{\left[1+\exp \left(\gamma_{0}+\gamma_{1} n p f_{t-1}+\gamma_{2}\left(s-s^{*}\right)_{t-1}+\gamma_{3}\left(i-i^{*}\right)_{t-1}+\gamma_{4} \mathrm{oil}_{t-1}\right)\right]} \\
p_{t}^{2} & =\frac{\exp \left(\eta_{0}+\eta_{1} n p f_{t-1}+\eta_{2}\left(s-s^{*}\right)_{t-1}+\eta_{3}\left(i-i^{*}\right)_{t-1}+\eta_{4} \mathrm{oil}_{t-1}\right)}{\left[1+\exp \left(\eta_{0}+\eta_{1} n p f_{t-1}+\eta_{2}\left(s-s^{*}\right)_{t-1}+\eta_{3}\left(i-i^{*}\right)_{t-1}+\eta_{4} \mathrm{oil}_{t-1}\right)\right]} .(3)
\end{aligned}
$$

Finally, we take as a benchmark the standard linear model frequently estimated in the literature (see, Brooks et al. 2004; Hau and Rey 2006) and specified as follows:

$$
r_{t}=\mu+\sum_{i=1}^{4} \phi_{i} r_{t-i}+\beta n p f_{t-1}+\sigma \varepsilon_{t}
$$

Further details on the estimation process and the employed data are given in the next section.

\section{Data description and empirical results}

The data used consist of quarterly observations on bilateral portfolio investment flows, expressed in US dollars, and the US dollar-Japanese yen exchange rate over the period 1988:01-2011:04. End of period exchange rates are retrieved from the IMF's International Financial Statistics, whereas portfolio investment flows are sourced by the US Treasury International Capital (TIC) System. ${ }^{7}$ Exchange rate changes are calculated as $r_{t}=100\left(E_{t} / E_{t-1}\right)$, where $E_{t}$ denotes the log exchange rate at time $t$. Net portfolio flows, by contrast, are constructed as the difference between portfolio inflows and outflows. Inflows and outflows are measured as net purchases and sales of domestic assets (equities and bonds) by foreign residents, and net purchases and sales

\footnotetext{
5 Note that failure to reject the null hypothesis of $H_{0}: \gamma_{1}=\eta_{1}=0$ suggests a fixed transition probabilities (FTP) model.

6 The asterisk refers to Japan.

7 For a detailed description of the TIC data, see Edison and Warnock (2008).
} 
of foreign assets (equities and bonds) by domestic residents, respectively. Following Hau and Rey (2006) among others, portfolio flows are normalized by the previous fourquarter averages. Positive figures imply portfolio inflows toward the US or outflows from Japan. ${ }^{8}$

Summary descriptive statistics along with Hansen test statistics and OLS and maximum likelihood (ML) estimates of the models described above are reported in Table 1. The linear (benchmark) model, broadly consistent with Brooks et al. (2004) and Hau and Rey (2006), confirms that portfolio flows do not have a significant effect on the dollar-yen exchange rate changes. The insignificant effect of portfolio flows may be due to the associated nonlinear dynamic link between the two variables.

The null hypothesis of linearity against the alternative of a Markov regimeswitching process cannot be tested directly using a standard likelihood ratio (LR) test. We properly test for multiple equilibria (more than one regime) against linearity using Hansen's (1992) test. The results (Table 1) support a two-state regime-switching model. The presence of a third state was tested and rejected.

Model 1 appears to be well identified (see Table 1). The standardized residuals exhibit no signs of linear or nonlinear dependence. The periods of appreciation and depreciation seem to be accurately selected by the smoothed probabilities, which clearly separates the two regimes. Figure 3 shows the plots for the dollar-yen exchange rate changes, $r_{t}$, along with the corresponding estimated smoothed probabilities. It appears that state one (two) is characterized by appreciation (depreciation) and low (high) volatility, with the volatility in the high state, $\sigma_{2}$, being twice as big as the volatility in the low regime, $\sigma_{1}$. The process is in the appreciation (low volatility) state for 34 quarters $(36.56 \%$, with an average duration of 8.50 quarters). For the remaining of the sample, the currency is characterized by depreciation and high volatility. The null hypotheses of $H_{0}: \mu_{1}=\mu_{2}$ and $H_{0}: \sigma_{1}=\sigma_{2}$ are rejected at any conventional significance level, further confirming that the Markov chain is driven by switches in the first as well as the second moment.

The appreciation periods of the US dollar (depreciation of the yen) are notably associated with the stock prices decline in 1990 as a result of the fifth monetary tightening policy implemented by the Bank of Japan and aimed to deal with the Japanese asset price bubble, the Japanese policy interventions along with the Asian financial crisis over the period 1995-1998, the quantitative easing policy in Japan over the period 2001-2003, and the decline in the Japanese long-term real rates compared to the US counterparts over the period April 2005-July 2006 (see Obstfeld 2009). Note that the yen has steadily appreciated against the US dollar since 2008 as a result of being acting as a safe haven currency beside the Swiss franc and the Australian dollar during this period.

In order to assess whether portfolio flows contribute to predict changes in the exchange rate, we need to both (1) analyze the sign (and significance) of the parameters of the time-varying transition probabilities (this will enable us to find whether the flows

\footnotetext{
8 As far as the control variables are concerned, the real oil price is the West Texas Intermediate (WTI) crude oil spot price (in dollars per barrel), deflated by the US Consumer Price Index (CPI). Stock market returns are log changes in the S\&P 500 and NIKKEI 225 stock price indexes. Data on stock prices, 3 month interest rates, oil price and the CPI have been retrieved from Datastream.
} 
Table 1 Descriptive statistics, Hansen test, and estimation results

\begin{tabular}{llllll}
\hline \multicolumn{2}{l}{ Descriptive statistics $^{\mathrm{a}}$} & & & & \\
\hline$r_{t}$ & Mean & SD & Skewness & Ex. Kurtosis & JB \\
$n p f_{t}$ & 0.583 & 4.741 & 0.486 & 0.476 & $4.694[0.095]$ \\
$\left(s-s^{*}\right)_{t}$ & 0.700 & 1.363 & -0.359 & 0.446 & $2.869[0.238]$ \\
$\left(i-i^{*}\right)_{t}$ & 2.676 & 7.627 & 0.090 & -0.079 & $0.155[0.925]$ \\
oil $_{t}$ & 2.209 & 2.193 & -0.193 & -1.130 & $5.706[0.057]$ \\
\hline
\end{tabular}

Markov-switching state dimension: Hansen test ${ }^{\mathrm{b}}$

\begin{tabular}{lll}
\hline $\begin{array}{l}\text { Standardized } \\
\text { LR test }\end{array}$ & $\begin{array}{l}\text { Linearity versus } \\
\text { two states }\end{array}$ & $\begin{array}{l}\text { Two states versus } \\
\text { three states }\end{array}$ \\
\hline$L R$ & 4.7753 & 0.4301 \\
$M=0$ & {$[0.0011]$} & {$[0.6427]$} \\
$M=1$ & {$[0.0023]$} & {$[0.6773]$} \\
$M=2$ & {$[0.0053]$} & {$[0.6945]$} \\
$M=3$ & {$[0.0061]$} & {$[0.7132]$} \\
$M=4$ & {$[0.0122]$} & {$[0.7263]$} \\
\hline
\end{tabular}

OLS and Markov-switching estimation results ${ }^{\mathrm{c}}$

\begin{tabular}{|c|c|c|c|c|c|c|}
\hline & \multicolumn{3}{|l|}{$\begin{array}{l}\text { Mean } \\
\text { equation }\end{array}$} & \multicolumn{3}{|c|}{$\begin{array}{l}\text { Transition } \\
\text { probabilities }\end{array}$} \\
\hline & Linear & Model 1 & Model 2 & & Model 1 & Model 2 \\
\hline$\mu_{1}$ & $\begin{array}{l}0.768 \\
(0.532)\end{array}$ & $\begin{array}{l}-3.191 \\
(0.288)\end{array}$ & $\begin{array}{l}-3.228 \\
(0.263)\end{array}$ & $\gamma_{0}$ & $\begin{array}{l}1.733 \\
(0.682)\end{array}$ & $\begin{array}{l}-1.455 \\
(0.759)\end{array}$ \\
\hline$\mu_{2}$ & & $\begin{array}{l}2.332 \\
(0.285)\end{array}$ & $\begin{array}{c}2.308 \\
(0.274)\end{array}$ & $\gamma_{1}$ & $\begin{array}{l}1.277 \\
(0.643)\end{array}$ & $\begin{array}{l}1.619 \\
(0.765)\end{array}$ \\
\hline$\beta$ & $\begin{array}{c}-0.220 \\
(0.370)\end{array}$ & & & $\gamma_{2}$ & & $\begin{array}{l}0.163 \\
(0.171)\end{array}$ \\
\hline$\phi_{1}$ & $\begin{array}{l}0.170 \\
(0.105)\end{array}$ & $\begin{array}{c}-0.233 \\
(0.084)\end{array}$ & $\begin{array}{c}-0.232 \\
(0.076)\end{array}$ & $\gamma_{3}$ & & $\begin{array}{l}0.905 \\
(0.150)\end{array}$ \\
\hline$\phi_{2}$ & $\begin{array}{l}-0.257 \\
(0.101)\end{array}$ & $\begin{array}{l}-0.561 \\
(0.078)\end{array}$ & $\begin{array}{l}-0.568 \\
(0.075)\end{array}$ & $\gamma_{4}$ & & $\begin{array}{c}-0.005 \\
(0.014)\end{array}$ \\
\hline$\sigma_{1}$ & $\begin{array}{l}4.601 \\
(0.330)\end{array}$ & $\begin{array}{l}5.478 \\
(1.621)\end{array}$ & $\begin{array}{l}5.569 \\
(1.552)\end{array}$ & $\eta_{0}$ & $\begin{array}{l}3.026 \\
(0.759)\end{array}$ & $\begin{array}{l}8.057 \\
(3.122)\end{array}$ \\
\hline \multirow[t]{4}{*}{$\sigma_{2}$} & & $\begin{array}{l}11.292 \\
(1.272)\end{array}$ & $\begin{array}{l}11.002 \\
(1.518)\end{array}$ & $\eta_{1}$ & $\begin{array}{l}-0.520 \\
(0.416)\end{array}$ & $\begin{array}{l}-1.116 \\
(0.879)\end{array}$ \\
\hline & & & & $\eta_{2}$ & & $\begin{array}{l}-0.046 \\
(0.078)\end{array}$ \\
\hline & & & & $\eta_{3}$ & & $\begin{array}{l}-0.988 \\
(0.517)\end{array}$ \\
\hline & & & & $\eta_{4}$ & & $\begin{array}{l}-0.046 \\
(0.023)\end{array}$ \\
\hline $\log L i k$ & -271.864 & -255.152 & -246.003 & & & \\
\hline
\end{tabular}


Table 1 continued

\begin{tabular}{|c|c|c|c|c|c|}
\hline \multicolumn{6}{|c|}{ OLS and Markov-switching estimation results ${ }^{\mathrm{c}}$} \\
\hline & \multicolumn{3}{|c|}{$\begin{array}{l}\text { Mean } \\
\text { equation }\end{array}$} & \multicolumn{2}{|l|}{$\begin{array}{l}\text { Transition } \\
\text { probabilities }\end{array}$} \\
\hline & Linear & Model 1 & Model 2 & Model 1 & Model 2 \\
\hline$L B_{(8)}$ & $\begin{array}{c}10.27 \\
{[0.113]}\end{array}$ & $\begin{array}{l}3.300 \\
{[0.192]}\end{array}$ & $\begin{array}{c}1.639 \\
{[0.440]}\end{array}$ & & \\
\hline$L B_{(8)}^{2}$ & $\begin{array}{c}0.374 \\
{[0.930]}\end{array}$ & $\begin{array}{l}3.268 \\
{[0.916]}\end{array}$ & $\begin{array}{l}4.904 \\
{[0.767]}\end{array}$ & & \\
\hline
\end{tabular}

$\overline{\mathrm{a}} r_{t}, n p f_{t},\left(s-s^{*}\right)_{t},\left(i-i^{*}\right)_{t}$, and oil $t$ indicate exchange rate changes, net portfolio flows, equity return differential, interest rate differential, and real oil price changes, respectively. JB is the Jarque-Bera test for normality. $P$ values are in square brackets [.]

$\mathrm{b}$ The Hansen's standardized likelihood ratio (LR) test $p$ values, reported in square brackets [.], are calculated according to the method described in Hansen (1992), using 1,000 random draws from the relevant limiting Gaussian processes and bandwidth parameter $M=0,1, \ldots, 4$. Test results for the presence of a third state are also reported

c The time-varying transition probabilities for Model 1 and Model 2 evolve according to Eqs. 2 and 3 , respectively. Autocorrelation and heteroscedasticity-consistent standard errors are used and represented in parentheses (.). $\mathrm{LB}_{(8)}$ and $\mathrm{LB}_{(8)}^{2}$ are, respectively, the Ljung and Box (1978) tests of significance of autocorrelations of eight lags on the standardized and squared standardized residuals. $P$ values are reported in square brackets [.]

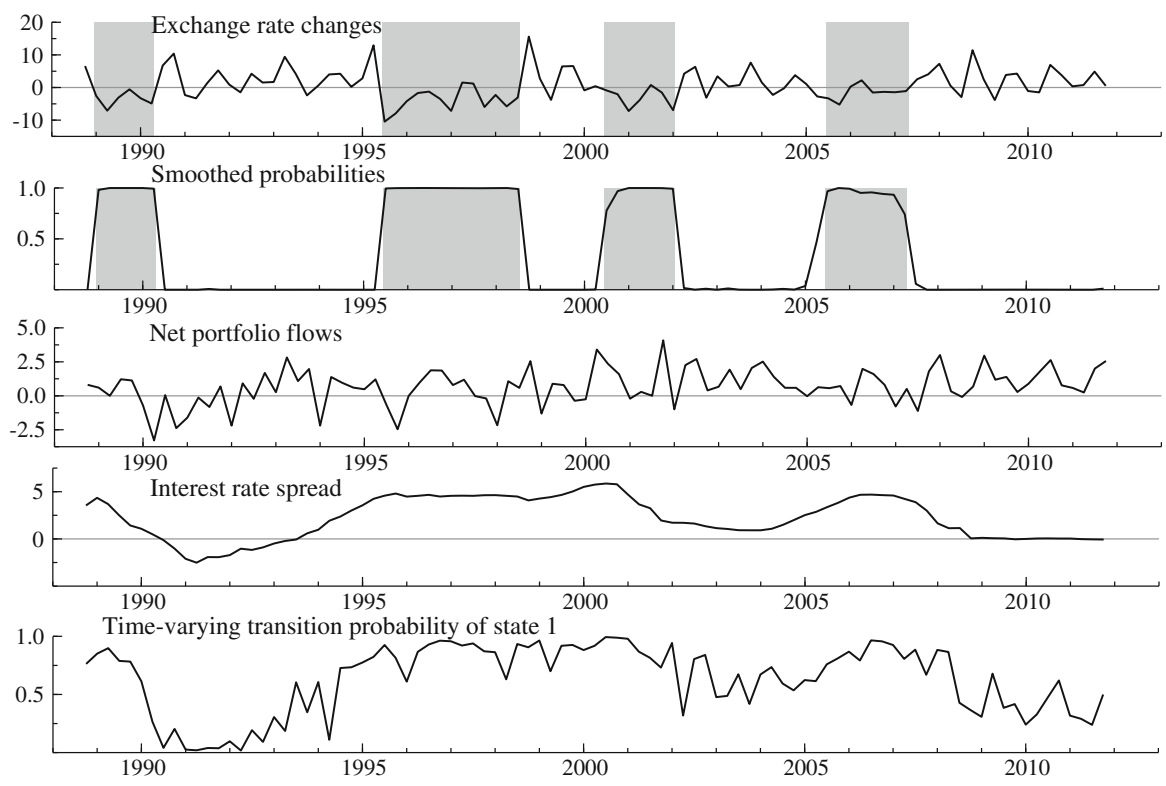

Fig. 3 Exchange rate changes, smoothed probabilities, net portfolio inflows, interest rate spread, and the time-varying transition probability of the appreciation (low variance) regime (state 1)

variable affects the probability of staying in, or switching regime) and (2) inquire, by looking at the temporal evolution of the time-varying transition probabilities, whether changes in regime are triggered by changes in the flows. 
The estimated coefficients for the transition probability functions, (Eq. 2), show that an increase (decrease) in the level of portfolio inflows raises (decreases) the probability of remaining in the appreciation and less volatile regime, since $\gamma_{1}$ is positive and significant $\left(\gamma_{1}=1.619\right)$. On the other hand, portfolio inflows do not appear to impact on exchange rate changes during depreciation and high volatility periods, with $\eta_{1}$ being not significant.

The evolution of the time-varying transition probabilities and the net portfolio inflows variable, $n p f_{t}$, are very informative. It is clear that the transition probabilities of remaining in the same state vary throughout the sample. Changes in the probability of remaining in the appreciation and less volatile regime, in particular, seem to be triggered by portfolio flow behavior (see Fig. 3). For example, the decline in the inflows toward the US associated with the September 11 terrorist attacks, the dotcom bubble burst, and the post-Lehman Brothers default period with the yen acting as a safe haven currency decreases the probability of remaining in the dollar appreciation (low volatility) regime $\left(p_{t}^{1}\right)$. On the other hand, the rise in the inflows associated with the Asian financial crisis in 1997-1998, the fall in the asset prices and the economic downturn in Japan over the period 2001-2003, and the drop in the Japanese real rates over the period 2005-2007 increase the probability of remaining in the dollar appreciation (low volatility) regime.

Our results are robust to the inclusion of the control variables (Model 2). The interest rate spread has a significant and positive effect only in the appreciation and low volatility state $\left(\gamma_{3}=0.905\right)$, although smaller than what observed for portfolio inflows $\left(\gamma_{3}<\gamma_{1}\right)$. More specifically, a higher US interest rate relative to the Japanese counterpart increases the probability of remaining in the appreciation and low volatility state. With regard to the changes in real oil prices, they have a negative effect $\left(\eta_{4}=-0.046\right)$ only during depreciation and high volatility periods. That is, an increase in the real oil price leads to a decrease in the probability of remaining in the depreciation and high volatility state, consistent with Lizardo and Mollick (2010). Lizardo and Mollick (2010) argued that a higher real oil price results in an appreciation of the US dollar especially against net importer countries' currencies such as Japan. By contrast, the stock return differential parameters $\left(\gamma_{2}, \eta_{2}\right)$, consistently with Hau and Rey (2006), are not significant.

\section{Conclusion}

In this paper, we have investigated the causality dynamics running from portfolio inflows into the US dollar-yen exchange rate changes using quarterly data over the period 1988:01-2011:04. By using a time-varying transition probability Markovswitching model, we contribute to the existing literature by showing that portfolio inflows from Japan toward the US result in an increase in the probability of remaining in the appreciation (less volatile) regime. This finding supports the view that investors behave differently when the market is in an appreciation compared to a depreciation state and when it is in a high rather than low volatility period. The observed state-dependent impact of the flows reflects the differences in the behavior of the yen compared to the US dollar in the foreign exchange market. Moreover, over the last 
two decades, both the US and Japan have undergone different economic cycles and macroeconomic conditions, thereby further inducing international investors to rebalance their portfolios across borders.

The results presented herein are robust to monetary policy, stock markets, and terms of trade shocks. Furthermore, they add new information, suggesting that portfolio inflows rather than monetary variables keep the domestic currency in the appreciation (low volatility) regime. The dynamic time-varying approach supports the appropriateness of the nonlinear framework adopted in this paper. The policy implication of our result is that portfolio flows are more efficacious in determining the currency dynamics, and therefore, credit controls on these flows can be used in order to pursue economic and financial stability.

Open Access This article is distributed under the terms of the Creative Commons Attribution 4.0 International License (http://creativecommons.org/licenses/by/4.0/), which permits unrestricted use, distribution, and reproduction in any medium, provided you give appropriate credit to the original author(s) and the source, provide a link to the Creative Commons license, and indicate if changes were made.

\section{References}

Amano RA, van Norden S (1998) Oil prices and the rise and fall of the US real exchange rate. J Int Money Finance 17(2):299-316

Botman D, de Carvalho Filho I, Lam WR (2013) The curious case of the yen as a safe haven currency: a forensic analysis. IMF working paper WP/13/228

Bernanke B (2000) Japanese monetary policy: a case of self-induced paralysis? In: Posen AS, Mikitani R (eds) Japan's financial crisis and its parallels to US experience. Institute for International Economics Special Report 13, Washington DC, pp 149-166

Brooks R, Edison H, Kumar MS, Slok T (2004) Exchange rates and capital flows. Eur Financ Manag 10(3):511-533

Caporale GM, Menla Ali F, Spagnolo N (2015) Exchange rate uncertainty and international portfolio flows: a multivariate GARCH-in-mean approach. J Int Money Finance 54:70-92

Chinn MD, Moore MJ (2011) Order flow and the monetary model of exchange rates: evidence from a novel data set. J Money Credit Bank 43(8):1599-1624

Edison HJ, Warnock FE (2008) Cross-border listings, capital controls, and equity flows to emerging markets. J Int Money Finance 27(6):1013-1027

Filardo AJ (1994) Business-cycle phases and their transitional dynamics. J Econ Bus Stat 12(3):299-308

Habib MM, Stracca L (2012) Getting beyond carry trade: what makes a safe haven currency? J Int Econ 87(1):50-64

Hansen BE (1992) The likelihood ratio test under nonstandard conditions: testing the Markov switching model of GNP. J Appl Econom 7(S1):61-82

Hau H, Rey H (2006) Exchange rates, equity prices, and capital flows. Rev Financ Stud 19(1):273-317

Hunter J, Menla Ali F (2014) Money demand instability and real exchange rate persistence in the monetary model of USD-JPY exchange rate. Econ Model 40:42-51

Jeanne O, Rose AK (2002) Noise trading and exchange rate regimes. Q J Econ 117(2):537-569

Lizardo R, Mollick A (2010) Oil price fluctuations and US dollar exchange rates. Energy Econ 32(2):399_ 408

Ljung GM, Box GEP (1978) On a measure of lack of fit in time series models. Biometrika 65(2):297-303

Lovcha Y, Perez-Laborda A (2013) Is exchange rate customer order flow relationship linear? Evidence from the Hungarian FX market. J Int Money Finance 35:20-35

Menla Ali F, Spagnolo F, Spagnolo N (2014) Exchange rates and net portfolio flows: a Markov switching approach. In: Mamon RS, Elliott RJ (eds) Hidden Markov models in finance, Volume II. Further Developments and Applications. Springer's International Series in Operations Research and Management Science, US, pp 117-132 
Obstfeld M (2009) Time of troubles: the yen and Japan's economy, 1985-2008. University of California at Berkeley, Mimeo

Ruelke JC, Frenkel MR, Stadtmann G (2010) Expectations on the yen/dollar exchange rate-evidence from the Wall Street Journal forecast poll. J Jpn Int Econ 24(3):355-368

Sarno L, Taylor M (2001) Official intervention in the foreign exchange market: is it effective and if so, how does it work? J Econ Lit 39(3):839-868

Sarno L, Tsiakas I, Ulloa B (2016) What drives international portfolio flows? J Int Money Finance 60:53-72

The Economist (2007) What keeps bankers awake at night? February 1st. http://www.economist.com/node/ 8633485 